\title{
correspondence
}

\section{The key to the universe}

SIR,-It is always dangerous to assume that others are less intelligent than oneself. In your editorial That $W$ as the Weak Force, That Was (3 February) you concede that "the initiated" found a certain amount to admire in the recent two hour programme, The Key to the Universe, but you add, patronisingly, "the uninitiated, which must have been $99.9 \%$ of the audience, can only have been thoroughly confused ...". You then stand cleverly on your head and accuse the production team of one fundamental mistake: "they underestimate the seriousmindedness of the audience".

The Key to the Universe, shown on BBC2 on Thursday, 27 January, had an audience of three million; Nigel Calders' book, written in association with the programme, was soon second in the Sunday Times best-seller list.

We believe the public has a right to know about all aspects of science, including the esoteric, and television has a duty to inform them. It is our experience that didactic programmes attract at most half-a-million viewers: far less if made in the patronising way you advocate. 1 assure you that we do not underestimate the serious-mindedness of our audience and we shall continue to cater for those whom you appear to dismiss as "the uninitiated".

Philip Daly

Head of Science and Features,

$B B C$ Television

\section{Lavoisier's originality}

SIR,-We have as little reason to put Lavoisier's scientific reputation on trial as had the Revolutionary Tribunal to question his loyalty to France. Gonzalez (December 9, page 504) reports that Lavoisier probably received, in 1767 , a copy of John Mayow's Opera Omnia Medico-Physica in a shipment of 118 books ordered for his personal library.

It is much too facile to assert that "Mayow recognised the existence of oxygen, which he called Spiritus nitro aereo, in 1674 ..." One might as well say that Lucretius recognised the existence of atoms 1800 years before Dalton, or Caesalpinus the circulation of blood 50 years before Harvey. If Mayow's writings were known to the 24-year-old Lavoisier in 1767, they were also known to other scientists in the preceding 93 years, yet chemistry had to wait until the 1770 s for the work of
Priestley, Scheele, and Lavoisier. The fact is that the idea of the Spiritus nitro aereo did not originate with Mayow, but derived, as Henry Guerlac has shown ${ }^{1}$, from earlier observations concerning nitre (potassium nitrate).

As a component of gun powder, nitre was associated with explosive heat and light, but it was also associated with cold, which it produces as it is dissolved in water. An aerial spirit of nitre was therefore invoked to explain the atmospheric phenomena of thunder and lightning, explosions so often accompanied by cold rain or hail. Since ancient times it was known that air is required for the heat of fires (for example in the use of blow pipes), and for the maintenance of animal life. Aristotle and Galen both felt that air helped to cool (to moderate) the animal body's heat. Hence in the seventeenth century an aerial spirit of nitre could be thought to provide both the heat and the coolness that the body required.

At Oxford in the years immediately preceding the young Mayow's work, Boyle and Hooke established with their vacuum pump that both a burning flame and the animal body require air; Hooke showed that the function of breathing is to supply this air rather than to squeeze by its motions the blood through the lungs, and Lower demonstrated that the blood undergoes a colour change as it passes through the aerated lungs. Much of this Mayow records in his book. He also records his own important experiments demonstrating that the combustion of certain materials, as well as respiration under certain circumstances, is accompanied by a decrease in the volume of air in an enclosed vessel. The progress of the seventeenth century scientists in understanding respiration has been lucidly summarised by Leonard Wilson ${ }^{2}$.

Mayow was close to a discovery of oxygen in thinking that only a special part of air is involved in combustion. and that only this part is contributed by air to the blood in respiration. But his nitro-aerial spirit does not qualify as oxygen for many reasons, the most imnortant of which are:

- It is not an ordinary material of definite mass or density, for Mavow asserts that it continues to exist in a vacuum, where it accounts for the conduction of light. Mavow did not claim that he had ever isolated it or measured its amount, and he did not prescribe any methods for doing so.
- Its qualities are too much dependent upon the circumstances impressed upon it, as for example its state of motion, which is to say that, like so much of the chemistry prior to Lavoisier, the nature of the thing was determined by too many qualifying adjectives.

- It is invoked to explain too wide a variety of fundamental natural phenomena, for example the nature of the sun, the presence of intense cold in the middle reaches of the atmosphere, the blueness of the sky, the nature of fire, the elasticity of air, the colours of different solid materials, and so $\mathrm{on}^{3}$. Incidentally, Mayow knew nothing of red blood cells and their pigment, as Gonzalez seems to imply. His explanation for the redness imparted to blood by air was that nitro-aerial particles are often of that colour, as is shown by the red distillate (nitrogen dioxide) which can be liberated by the heating of acidic nitre.

Thus it is hardly fair to assert that Lavoisier's discovery of oxygen was anticipated by Mayow, or that Lavoisier was guilty of scientific cheating in failing to give credit to him. Lavoisier's conception of oxygen was very different from Mayow's idea of the nitro-aerial spirit. And. as Guerlac has pointed out ${ }^{4}$. Lavoisier's achievement was more fundamental even than the discovery of oxygen itself, for he was the first fully to realise that a host of material substances can exist in the gaseous state, and that the balance sheets of chemical processes must account for the materials of gases as well as of solids and liquids. Throughout his relatively short life, Lavoisier was recognised by his contemporaries as a man of exceptional genius. The day after Lavoisier was executed. the brilliant mathematician Lagrange remarked: "Only a moment to cut off that head, and a hundred years may not give us another like it"s.

\section{T. F SHFRMAN}

\section{Oberlin College.} Ohio 44074

\footnotetext{
1 Guerlac. H.. "John Marow and the acrial nitre." Congres intermationth de rllistoire dos science" Actes VII, 332-349. (Paris, 1953). Alvo "The (1954)

2 Wilson. L.. "The Transformation of Ancient Concents of Respiration in the Seventeenth century "

3 Mavow. J., Medico-Phrsical W'ork (Re-issue edition of The Alembic Cluh. Fdinburgh, 1957. An Fnelish translation

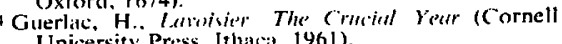
Unicersity Press. Ithaca, 1961). Mckie, P. Antrine I.torisier. 292 (Collier Books.
New York. 1962. A reprint of the Schuman cdition of (952).
} 